\title{
An high Mn(II)-tolerance strain, Bacillus thuringiensis HM7, isolated from manganese ore and its biosorption characteristics
}

\author{
Huimin Huang ${ }^{1}$, Yunlin Zhao ${ }^{1}$, Zhenggang Xu ${ }^{\text {Corresp., }}{ }^{1}$, Yi Ding ${ }^{1}$, Xiaomei Zhou ${ }^{2}$, Meng Dong ${ }^{2}$ \\ ${ }^{1}$ Hunan Research Center of Engineering Technology for Utilization of Environmental and Resources Plant, Central South University of Forestry and \\ Technology, Changsha, Hunan, China \\ 2 School of Material and Chemical Engineering, Hunan city university, Yiyang, Hunan, China \\ Corresponding Author: Zhenggang Xu \\ Email address: rssq198677@163.com
}

Microorganism plays a significant part in detoxifying and immobilizing excessive metals. The present research isolated a strain (HM7) with high $\mathrm{Mn}$ (II) tolerance from $\mathrm{Mn}(\mathrm{II})$ contaminated soil samples. The $16 \mathrm{~S}$ rDNA sequence analysis showed that HM7 had a $99 \%$ similarity to Bacillus thuringiensis, which can survive under a high concentration 4,000 $\mathrm{mg} / \mathrm{L}$ of $\mathrm{Mn}(\mathrm{II})$, and the highest removal rate was up to $95.04 \%$ at the concentration of 400 $\mathrm{mg} / \mathrm{L}$. The highest $\mathrm{Mn}(\mathrm{II})$ removal rate was detected at the contact time $72 \mathrm{~h}$, temperature

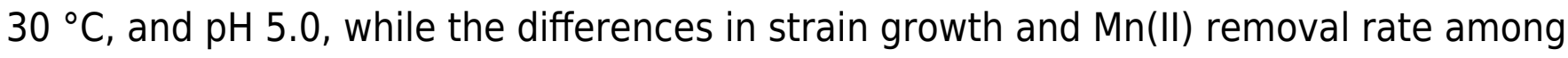
different inoculation doses were insignificant. Scanning electron microscopy indicated $B$. thuringiensis HM7 cells appeared irregular and cracked under Mn(II) stress. Fourier transform infrared exhibited that functional groups like carboxyl, hydroxyl, amino, sulfhydryl groups, and amide bands might take part in the complexation of $\mathrm{Mn}(\mathrm{II})$. In addition, HM7 suggested the ability of indoleacetic acid production, siderophore production, and $\mathrm{P}^{\prime}$ solubilization potential. Therefore, HM7 might have a potential to promote metal absorption by changing the form of heavy metals, and the experiments supported the application of $B$. thuringiensis HM7 as a biological adsorbent in $\mathrm{Mn}$ (II) contaminated environment remediation. 
1 An high Mn(II)-tolerance strain, Bacillus thuringiensis HM7, isolated from manganese ore and

2

3

$10 *$ Corresponding author:

11 Zhenggang Xu

12 E-mail: rssq198677@163.com

13 Tel: +8618684945647

\section{its biosorption characteristics}

$$
\text { Huimin Huang }{ }^{1} \text {, Yunlin Zhao }{ }^{1} \text {, Zhenggang } \mathrm{Xu}^{1,2}{ }^{*} \text {, Yi Ding }{ }^{1} \text {, Xiaomei Zhou }{ }^{2} \text {, }
$$
Meng Dong ${ }^{2}$

${ }^{1}$ Hunan Research Center of Engineering Technology for Utilization of Environmental and Resources Plant, Central South University of Forestry and Technology, Changsha, Hunan, China.

${ }^{2}$ School of Material and Chemical Engineering, Hunan City University, Yiyang, Hunan, China. 
14 Abstract Microorganism plays a significant part in detoxifying and immobilizing excessive metals. The present research isolated a strain (HM7) with high $\mathrm{Mn}(\mathrm{II})$ tolerance from $\mathrm{Mn}(\mathrm{II})$-contaminated soil samples. The $16 \mathrm{~S}$ rDNA sequence analysis showed that HM7 had a 99\% similarity to Bacillus thuringiensis, which can survive under a high concentration $4,000 \mathrm{mg} / \mathrm{L}$ of $\mathrm{Mn}(\mathrm{II})$, and the highest removal rate was up to $95.04 \%$ at the concentration of 400 $\mathrm{mg} / \mathrm{L}$. The highest $\mathrm{Mn}(\mathrm{II})$ removal rate was detected at the contact time $72 \mathrm{~h}$, temperature $30{ }^{\circ} \mathrm{C}$, and $\mathrm{pH} 5.0$, while the differences in strain growth and $\mathrm{Mn}(\mathrm{II})$ removal rate among different inoculation doses were insignificant. Scanning electron microscopy indicated B. thuringiensis HM7 cells appeared irregular and cracked under Mn(II) stress. Fourier transform infrared exhibited that functional groups like carboxyl, hydroxyl, amino, sulfhydryl groups, and amide bands might take part in the complexation of Mn(II). In addition, HM7 suggested the ability of indoleacetic acid production, siderophore production, and $\mathrm{P}^{\prime}$ solubilization potential. Therefore, HM7 might have a potential to promote metal absorption by changing the form of heavy metals, and the experiments supported the application of $B$. thuringiensis HM7 as a biological adsorbent in $\mathrm{Mn}(\mathrm{II})$ contaminated environment remediation. 


\section{Introduction}

In recent years, with the rapid development of industrialization, heavy metal pollution has become a great concern worldwide(Li et al. 2014). In particular, waste tailings contain high levels of toxic heavy metals, causing severe heavy metal pollution in the soil nearby, and harming human health through food chain enrichment(Klimek 2012; Zaidi et al. 2006). Thus, the research on the restoration of heavy metal pollution in soil and water is imminent. Soil is an important part of the earth's ecological environment, and the accumulation of heavy metals in polluted soil is not conducive to human life and health(Huang et al. 2019). Heavy metals in polluted soils are characterized by poor mobility, strong concealment, long retention period, and difficulty in degradation. They not only affect soil structure and nutrients, but also affect the surrounding environment and human health through infiltration, rainwater leaching and food chain(Chen \& Zhu 1999; Kamaludeen et al. 2003). Manganese $(\mathrm{Mn})$ is an essential trace element in organisms, but excess $\mathrm{Mn}$ (II) causes a great damage to the metabolic activity of organisms. Moreover, the toxicity of $\mathrm{Mn}$ (II) has been confirmed that it may be the second limiting factor of acidic soil(Mou et al. 2011). In Mn ore, the concentration of Mn(II) is pretty high, and metals are difficult to be absorbed and degraded, they may enter the food chain in the environment, resulting in toxic, carcinogenic and mutagenic effects of organisms. Therefore, how to repair the Mn-contaminated pollution has become an important issue to be solved in the current exhibition.

In order to solve metal pollution problems, lots of conventional methods of removal and detoxification of $\mathrm{Mn}$ (II) from contaminated environment have been reported such as ion exchange, chemical precipitation, electro dialysis, reverse osmosis, filtration, solvent extraction, and chemical oxidation-reduction(Jarpa et al. 2016). However, most of the traditional methods are inefficient, expensive, unsuitable and producing secondary pollutants such as toxic byproducts(Kang et al. 2015; Wang et al. 2017). Therefore, it is imperative to find an effective and eco-friendly method with the detoxification and removal of $\mathrm{Mn}$ (II) for the safety of environment. As a safe, green, economical and simple treatment method, bioremediation has been widely used in contaminated soil management. It mainly includes three aspects of plant, animal and microbial restoration. Among them, microbial remediation mainly refers to the microbes in the environment to reduce the toxicity of heavy metals in the soil through the action of redox, precipitation and absorption of heavy metals(Chanmugathas et al. 1986). Researches have shown that large amounts of microorganisms (fungi, bacteria and yeasts) play a significant role in bioremediation, they can 
55

change the form of the presence and reduce the toxicity of heavy metals by biosorption, oxidation-reduction reactions, and dissolving(Glick 2010; N et al. 2009; Rajkumar et al. 2010). Hullo et al.(2001) demonstrated Bacillus subtilis spore-forming colonies were darker at higher $\mathrm{Mn}(\mathrm{II})$ concentrations, which had spores that express $\mathrm{Mn}(\mathrm{II})$ oxidize. This was mainly because the CotA protein on Bacillus subtilis was involved in the metabolism in protection against hydrogen peroxide. Lysinibacillus sp. grown at the $\mathrm{Mn}(\mathrm{II})$ concentrations of $1 \mathrm{mM}$, the total $\mathrm{Mn}(\mathrm{II})$ removal rate reached $94.67 \%$ and $55.94 \%$ of Mn (II) was oxidized, this was because that most Mn(II) oxides in nature were formed through the life activities of microorganisms, microorganisms catalyzed the conversion of $\mathrm{Mn}$ (II) into oxides and improved the oxidation rate of Mn(II) (Tang et al. 2016). However, there are many factors influence the composition of microbial community. Researchers have detected that characteristics of environmental (e.g., metal concentration, temperature, $\mathrm{pH}$, etc.) affected the cell biological activity and community(Tuffin et al. 2006; Wang et al. 2011).

Furthermore, microbes can not only directly repair the environment and remove heavy metals, but also can be combined with phytoremediation, mainly in the following aspects: (i) Microorganisms, such as mycorrhiza and endophytes, form a union with plant roots to enhance plant survival and growth rate by enhancing plant resistance(Moreira et al. 2019; Orlowska E et al. 2011). (ii) Microorganisms can optimize plant rhizosphere environment by converting heavy metal forms and improve plant survival conditions(Kamaludeen et al. 2003; Rajkumar et al. 2010). (iii) In synergy and symbiosis of plants and microorganisms, microorganisms metabolize and secrete plant growth-promoting substances, then increase plant root absorption, and the plant's ability to transport heavy metals(Aboushanab et al. 2008; Compant et al. 2010). Wani demonstrated that the Bacillus sp. had the promotion of plant growth, the adsorption of $\mathrm{Zn}$ and $\mathrm{Pb}$, the production of siderophores and solubilization of insoluble phosphorus (P)(Wani et al. 2007). Many studies have shown that microorganisms can not only adsorb heavy metals, but also promote plant transport of heavy metals and plant-growth (Table 1).

There is a valuable microbe bank in ore area with tremendous microbe resources. In the previous study, we isolated two high-efficiency $\mathrm{Mn}(\mathrm{II})$-resistant bacteria from Xiangtan $\mathrm{Mn}(\mathrm{II})$ ore and analysed the tolerance characteristics of the strain. The present research was aimed to isolate $\mathrm{Mn}$ (II)-tolerant bacteria with the ability to promote plant growth from Mn(II)-polluted water. To gain more characteristic information on this Mn(II)-tolerant strain, relevant detects including 16S rDNA sequence analysis, physiological and biochemical test were performed 
82 to figure out the properties of the strain. Besides, the Mn(II) adsorption capacity of the tolerant strains and optimal biosorption conditions were detected through different parameters experiments. Scanning electron microscopy (SEM) analysis was carried out to reveal the cell surface changes in cell-surface after biosorption. Fourier transform infrared (FTIR) techniques were utilized to detect the functional groups in the strain surface. Finally, the property of plant growth promoting and antibiotic resistance of the strain were tested. The main objective of the study was to provide an effective and environmentally friendly biosorbents which contribute to the bioremediation of heavy metal contaminated soils and water.

\section{Materials and methods}

\section{Samples and main materials}

Soil samples (the content of $\mathrm{Mn}(\mathrm{II})$ was about $15225.17 \mathrm{mg} / \mathrm{kg}, \mathrm{pH}$ was about 4.5-4.7) were collected from Xiangtan Mn ore, Hunan, China $\left(112^{\circ} 45^{\prime} \mathrm{E} \sim 122^{\circ} 55^{\prime} \mathrm{E}, 2^{\circ} 53^{\prime} \mathrm{N} \sim 28^{\circ} 03^{\prime} \mathrm{N}\right)$, which has serious heavy metal pollution(Ouyang et al. 2016). Samples were taken from 0-10 cm soil from Mn(II) ore wasteland, 100 mesh sieved, mixed evenly and placed in a sterile centrifugal tube, and stored at $-80^{\circ} \mathrm{C}$ in the laboratory.

Basic beef-Protein medium: Peptone $1 \%$, beef extract $0.3 \%$, and $\mathrm{NaCl} 0.5 \%$, pH 5.6-6.0 (plus agar $1.5 \%$ for solid medium); Selection medium: $\mathrm{MnSO}_{4} \cdot \mathrm{H}_{2} \mathrm{O}$ was added to the basal medium and adjusted to the desired concentration. Required $\mathrm{pH}$ was adjusted by $1 \mathrm{~mol} / \mathrm{L} \mathrm{NaOH}$ and $1 \mathrm{~mol} / \mathrm{L} \mathrm{HCl}$.

\section{Selection of Mn(II)-tolerant bacterial strains}

Ten gram of soil sample was dissolved in $90 \mathrm{ml}$ of distilled water and coated on $500 \mathrm{mg} / \mathrm{L} \mathrm{Mn}(\mathrm{II}) \mathrm{solid}$ selection medium (basic beef-Protein medium), at $30^{\circ} \mathrm{C}$ for 3 days cultured in a biochemical incubator (SPX-250B, China). In the aseptic console (SW-CJ-2F, China), the selected colonies were subsequent culturing/ sub-transferring incubated with increasing concentrations of $\mathrm{Mn}(\mathrm{II})(500,1,000,1,500,2,000,3,000$, and $4,000 \mathrm{mg} / \mathrm{L})$ at $30{ }^{\circ} \mathrm{C}$ for 3 days in solid basic beef-Protein medium. Finally, the high Mn(II)-tolerant strain was picked up and repeatedly streaked on solid basal medium to obtain pure culture bacteria, stored at $-4{ }^{\circ} \mathrm{C}$ in the Beef-Protein slant medium.

\section{Identification of the Mn(II)-tolerant strain}

\section{Bacterial characterisation}

By screening, a Mn(II)-tolerant strain was isolated and characterised morphologically, and biochemically. Gram staining, catalase test, hydrogen sulphide test, methyl red test, Voges Proskauer test, oxidase test, glucose test, 
109 and gelatine liquefaction test were detected by the standard methods in Bergey's Manual of Determinative

110 Bacteriology(Holt \& John 1994).

\section{16S rDNA-based identification}

112 To determine the classification of the strain, 16S rDNA analysis was performed on HM7. The strain was 113 subjected to PCR amplification using bacterial universal primers 1492R (5' TAC GGY TAC CTT GTT ACG ACT T $1143^{\prime}$ ) and 27F (5' AGA GTT TGA TCM TGG CTC AG 3'). Purification and sequencing (Illumina Hiseq 2500, 115 California, USA) were carried out by Shanghai Majorbio Technology Company, China (http://www.majorbio.com).

116 The obtained nucleotide sequence data was deposited in the NCBI GeneBank sequence database, the online program 117 BLAST was used to figure out the relevant sequences with known taxonomic information in the Genebank 118 (http://www.ncbi.nlm.nih.gov/BLAST) to identify the strain. The phylogenetic tree was built by software Mega 119 7.0(Kumar et al. 2016) which based on the neighbour-joining(Saitou \& Nei 1987).

\section{Biosorption tests}

121 Experimental cultured conditions as follows, the concentration of $\mathrm{Mn}$ (II) was $1,000 \mathrm{mg} / \mathrm{L}$, the cultured time

was $72 \mathrm{~h}$, the temperature was $30^{\circ} \mathrm{C}$, the inoculation biomass was $1 \mathrm{~mL}$ (with an approximate optical density of 1.0 at $600 \mathrm{~nm}$, approximately $1.0 \times 10^{13}$ cells/L), the $\mathrm{pH}$ was 5.6-6.0. All tests were done in $250 \mathrm{ml}$ conical Erlenmeyer flasks with $100 \mathrm{ml}$ selection medium on a rotary shaker at $120 \mathrm{r} / \mathrm{min}$ (ZHWY-211C, China).

In order to detect the effect of different factors on the adsorption of $\mathrm{Mn}^{2+}$ by the strain, one of the corresponding parameters were changed according to the above conditions. (i) Effect of the different initial Mn(II) concentrations: the cultured solutions were prepared containing $\mathrm{Mn}^{2+}$ at concentrations of $0,200,400,600,800$, 1,000, 2,000, 3,000, 4,000, 5,000, 7,500, and 10,000 mg/L with $\mathrm{MnSO}_{4} \cdot \mathrm{H}_{2} \mathrm{O}$. (ii) Effect of the cultured time: the contact time was investigated of $0,12,24,36,48,60,72,84,96,108,120$, and $144 \mathrm{~h}$. (iii) Effect of the temperature: the biosorption tests were studied at $5,10,15,20,25,30,35$, and $40{ }^{\circ} \mathrm{C}$. (iv) Effect of the inoculation biomass: the cultured solutions inoculated $0.1,0.5,0.5,1.0,2.0$, and $5.0 \mathrm{~mL}$ of biomass separately. (v) Effect of the $\mathrm{pH}$ : the $\mathrm{pH}$ of the culture solution was adjusted to $3.0,4.0,5.0,6.0,7.0,8.0$, and 9.0 by using $1 \mathrm{~mol} / \mathrm{L} \mathrm{HCl}$ and $1 \mathrm{~mol} / \mathrm{L} \mathrm{NaOH}$.

For the purpose of detecting the strain growth and $\mathrm{Mn}(\mathrm{II})$ removal rate in the tests, the sample were carried out at a specific time. The growth of HM7 was determined by ultraviolet spectrophotometer (UV-2450, China) at 600 $\mathrm{nm}\left(\mathrm{OD}_{600}\right)$. The specific method was preheating the ultraviolet spectrophotometer for 20 min before the 
136

137

138

139

140

141

142

143

144

145

146

147

148

149

150

151

152

153

154

155

156

157

experiment, and adjusting the wavelength to $600 \mathrm{~nm}$. After the sample reaction was completed, $3-5 \mathrm{~mL}$ of the bacteria suspension were taken into the quartz cuvette and placed it in the UV spectrophotometer to read the $\mathrm{OD}_{600}$ value of the strain immediately. Than the bacteria suspension was centrifuged at 4,000 rpm for $15 \mathrm{~min}$ (TD5A, China), and the residual Mn(II) concentration of the supernatant was analyzed by flame atomic absorption spectrophotometer (AA7000, Japan). The $\mathrm{pH}$ was tested by Rex laboratory $\mathrm{pH}$ meter (PHS-3C, China). All experimental tests were repeated three times, data processing and variance analysis were determined by SPSS 20.0 (Li \& Chen 2010).

$\mathrm{Q}=\frac{\left(C_{0}-C_{e}\right)}{C_{0}} \times 100 \%$

Where $\mathrm{Q}$ is removal rate of $\mathrm{Mn}(\mathrm{II}), \mathrm{C}_{0}$ is the initial concentration of $\mathrm{Mn}(\mathrm{II})(\mathrm{mg} / \mathrm{L})$, and $\mathrm{C}_{\mathrm{e}}$ is the residual concentration of $\mathrm{Mn}(\mathrm{II})(\mathrm{mg} / \mathrm{L})$.

\section{Scanning electron microscopy (SEM) analysis}

SEM analysis (JSM-6380LV, Japan) was used for the purpose of observing the changes in surface morphology of cells before and after adsorption of $\mathrm{Mn}^{2+}$ (under the conditions of initial $\mathrm{Mn}$ (II) concentration 1,000 $\mathrm{mg} / \mathrm{L}$, temperature $30{ }^{\circ} \mathrm{C}$ and $\mathrm{pH} 5.6-5.8$ for $72 \mathrm{~h}$ ). $\mathrm{Mn}$ (II)-loaded and $\mathrm{Mn}(\mathrm{II})$-free strain samples were examined after cell fixation with glutaraldehyde, dehydrated with ethanol and freeze-drying with a vacuum.

\section{Fourier transform infrared (FTIR) analysis}

In order to figure out the main chemical functional groups of $\mathrm{Mn}^{2+}$ adsorbed by the cells, the strains before and after the adsorption of $\mathrm{Mn}^{2+}$ were analyzed by FTIR (NICOLET 5700, USA). After culturing the strain under the conditions of initial $\mathrm{Mn}$ (II) concentration $1,000 \mathrm{mg} / \mathrm{L}$, temperature $30{ }^{\circ} \mathrm{C}$ and $\mathrm{pH} 5.6-5.8$ for $72 \mathrm{~h}$ in a liquid medium, the cells were collected by centrifugation and washed three times with deionized water, after vacuum freeze-drying, a small number of lyophilized cells were mixed with $\mathrm{KBr}$, pressed at $10 \mathrm{t} / \mathrm{cm}^{2}$ for 1 min, and determined by FTIR spectrometer (Wave number range of $400 \mathrm{~cm}^{-1}-4000 \mathrm{~cm}^{-1}$ ).

\section{Property of plant growth promoting and antibiotic resistance of the strain}

To figure out the promoting potential of the strain, property of plant growth promoting and antibiotic resistance were checked. The test of Indole acetic acid (IAA) of the strain was detected by the method from Sheng et al.(Sheng et al. 2008a). Mineral phosphate solubilization activity of the strain was determined in the Pikovskayas medium(Biswas 2018). The siderophores production of the strain was detected by the CAS plate method (Schwyn \& 
163 Neilands 1987). The antibiotic resistance of the strain was tested in the Muller-Hinton agar medium by disk

164 diffusion method(Bharagava \& Mishra 2017).

\section{Result and Analysis}

\section{Selection of the optimal Mn(II)-resistant strain}

In this study, a highly effective Mn(II)-tolerant strain HM7 was isolated from the soil of Mn ore by gradient acclimation culture. HM7 could tolerate $4,000 \mathrm{mg} / \mathrm{L}$ of $\mathrm{Mn}(\mathrm{II})$ concentration in screening tests and the removal rate of at low concentration $(400 \mathrm{mg} / \mathrm{L})$ reached up to $95 \%$. The strain was used for further identification and analysis of Mn(II) removal properties.

171

172

173

174

\section{Characterization and molecular identification of HM7}

According to morphological, biochemical and physiological tests, HM7 was identified as a rod-shaped bacterium. Hydrogen sulphide test was negative, while Gram-staining, catalase, methyl red, Voges Proskauer, oxidase, glucose, and gelatine tests were positive (Table 2).

HM7 was submitted to $16 \mathrm{~S}$ rDNA gene sequence analysis for further confirm. The sequence of $16 \mathrm{~S}$ rDNA of HM7 was subjected to GenBank (accession number MG787231). Searched for the similar strain with known DNA sequences on the National Center for Biotechnology Information (NCBI) by using the BLAST program (https://blast.ncbi.nlm.nih.gov/Blast.cgi). The results indicated that HM7 had a close genetic relatedness of Bacillus and 99\% homology to Bacillus thuringiensis (B. thuringiensis) (ACNF01000156). The phylogenetic tree (neighbour-joining) was constructed by MEGA7(Kumar et al. 2016) (Fig. 1). The higher identical value confirmed HM7 to be B. thuringiensis and was named B. thuringiensis HM7 in the study.

\section{Characteristics of biosorption under different culture conditions}

\section{Effect of initial Mn(II) concentration on biosorption}

The effect of initial Mn(II) concentration on biosorption by B. thuringiensis HM7 was carried out over a range of $0-10,000 \mathrm{mg} / \mathrm{L}$. The results showed that the growth of HM7 within a certain $\mathrm{Mn}$ (II) concentration range (0-800 $\mathrm{mg} / \mathrm{L}$ ) were larger than without $\mathrm{Mn}(\mathrm{II})$. The strain growth reached equilibrium, and the maximum $\mathrm{OD}_{600}$ was 1.90 at $600 \mathrm{mg} / \mathrm{L}$ of $\mathrm{Mn}(\mathrm{II})$. As an essential element of biological growth, $\mathrm{Mn}(\mathrm{II})$ could promote the growth of bacteria at low $\mathrm{Mn}(\mathrm{II})$ concentration $(0-800 \mathrm{mg} / \mathrm{L})$. However, when the concentration was more than 2,000 $\mathrm{mg} / \mathrm{L}$, OD600 had a significant downward trend and growth inhibition appeared, HM7 could hardly grow at 4,000 $\mathrm{mg} / \mathrm{L}$ of Mn(II). This 
may be due to with increased initial Mn(II) concentration decreased the microbial activities, and finally heavy metal toxicity inhibited the growth of the bacteria (Fig. 2). Microorganisms mainly provide energy for life activities through respiration. Under the stress of high concentrations of heavy metals, oxygen consumption in respiration was significantly reduced, microbial respiration was weakened, and microbial activity was significantly inhibited(Crane et al. 2010). In addition, high concentrations of Mn stimulated the production of a large number of reactive oxygen species (ROS), and ROS could oxidize cell membrane lipids, functional proteins, DNA and other biological macromolecules, resulting in cell damage(Gong et al. 2012).

The $M n(I I)$ removal rate first increased and then decreased with the increased of $M n(I I)$ concentration, the maximum removal rate was $95.04 \%$ at $400 \mathrm{mg} / \mathrm{L}$. These results indicated that when the strain provided excessive active adsorption sites, at lower concentrations, all metal ions in the solution would interact with the binding site, so the percentage of biosorption was likely to be higher than at high ion concentrations. However, an increase in the concentration of $\mathrm{Mn}$ (II) might lead to competition at the adsorption sites and a decrease in microbial activity.so the biosorption rate declined(Ling et al. 2011; Yu et al. 2013).

Meanwhile, the experimental results indicated that the growth of $B$. thuringiensis $\mathrm{HM} 7\left(\mathrm{OD}_{600}\right)$ correlated with $\mathrm{pH}(\mathrm{r}=0.951, P<0.05)$. Before the experimental reaction, the $\mathrm{pH}$ in the solution was 5.6-5.8, after reacting with different concentrations of $\mathrm{Mn}^{2+}$, the $\mathrm{pH}$ in the solution varied from 5.8 to 8.1. Therefore, we speculated that HM7 might release some alkaline substances during its growth or reaction with $\mathrm{Mn}(\mathrm{II})$.. In a certain concentration range of $\mathrm{Mn}(\mathrm{II})$, the $\mathrm{pH}$ and $\mathrm{OD}_{600}$ increased with the increase of concentration $(0-600 \mathrm{mg} / \mathrm{L})$, while, at concentrations of $600-10,000 \mathrm{mg} / \mathrm{L}, \mathrm{OD}_{600}$ and $\mathrm{pH}$ decreased gradually, and the solution $\mathrm{pH}$ from weakly alkaline to weakly acidic. This could be described that the oxidation reaction of $\mathrm{MnO}_{2}$ ionic oxidation involved oxygen atoms in hydroxyl ions, and a large amount of $\mathrm{H}^{+}$in $\mathrm{O}-\mathrm{H}$ was exchanged with $\mathrm{Mn}^{2+}$ as the concentration of $\mathrm{Mn}(\mathrm{II})$ increased, resulting in low pH of the system(Wang et al. 2015).

\section{Effect of contact time on biosorption}

The growth of $B$. thuringiensis HM7 and the removal rate of heavy metal increased rapidly in the beginning, but after $72 \mathrm{~h}$ the rate of biosorption and the growth of HM7 slowed down and reached an equilibrium with highest Mn(II) removal rate of $56.35 \%$ at $108 \mathrm{~h}$ (Fig. 3a). The growth of HM7 was positively correlated with the removal rate of $\mathrm{Mn}(\mathrm{II})(\mathrm{r}=0.97, \mathrm{P}<0.05)$. Due to the high affinity of the free $\mathrm{Mn}(\mathrm{II})$ binding sites on the biosorbent, the 
217 biosorption rate of $\mathrm{Mn}(\mathrm{II})$ was highest at the start time, but slowed and reached equilibrium after about $108 \mathrm{~h}$. It

218 might be described that when the increased biomass provided sufficient active adsorption sites on the cell surface to

219 interact with $\mathrm{Mn}(\mathrm{II})$, and the removal rate increased. But when the biomass increased continuously, excess biomass

220 would aggregate part of cells, and less surface area exposured, which resulted in insufficient adsorption sites for the

221 biosorption and no excess $\mathrm{Mn}(\mathrm{II})$ adsorbed, indicating that equilibrium concentrations might be reached. In addition,

222 the growth of HM7 was correlated with $\mathrm{pH}(\mathrm{S}$ Fig. 1) $(\mathrm{r}=0.95, \mathrm{P}<0.05)$, showing that some alkaline substances

223 might be released when bacteria adsorbed $\mathrm{Mn}(\mathrm{II})$.

\section{Effect of temperature on biosorption}

With increasing temperature, the removal rate and biomass were raised first and then decreased (Fig. 3b). At

low temperatures $\left(5-10^{\circ} \mathrm{C}\right)$, B. thuringiensis HM7 could not grow and $\mathrm{Mn}(\mathrm{II})$ removal rates were extremely low, the removal rate and the growth of $\mathrm{HM} 7$ increased with increasing temperatures from 5 to $30^{\circ} \mathrm{C}$, the maximum biomass was $1.66\left(\mathrm{OD}_{600}\right)$ and removal rate reached $57.68 \%$ at $30^{\circ} \mathrm{C}$. When the temperature was higher than $35{ }^{\circ} \mathrm{C}$, the adsorption capacity and growth of the strain both decreased, this may be due to the temperature was too high, and affect the activity of the extracellular polymer, thereby reducing the biosorption of metal. It was observed that extreme temperatures reduced HM7 growth and Mn(II) oxidation, this was because excessive temperatures could lead to RNA pyrolysis, protein denaturation, and microbes to stop growing or dying. On the other hand, a low temperature would reduce the metabolism of microorganisms, the fluidity of the membrane was weak and the function of the transport system was impeded, so that nutrients could not enter the cell quickly, resulting in a low growth rate(Hao et al. 2016). Besides, the $\mathrm{pH}$ in solution correlated with the growth of HM7 and the strain might release alkaline substances (S Fig. 1). With the increased of temperature, the growth of the strain increased and the $\mathrm{pH}$ of the corresponding solution also increased continuously ( $\mathrm{r}=0.97, P<0.05)$, and this may be related to microbial adsorption of heavy metals.

\section{Effect of inoculation dose on biosorption}

The final biomass, removal rate, and $\mathrm{pH}$ were stable after $72 \mathrm{~h}$ of culturing with different initial inoculation dose which under the same nutritional conditions (Fig. 3c and S Fig. 1). As the inoculum increased, the growth of $B$. thuringiensis $\mathrm{HM} 7$ and the removal rate of $\mathrm{Mn}(\mathrm{II})$ did not change significantly. When the inoculation dose was 
244

245

246

247

248

249

250

251

252

253

254

255

256

257

258

259

260

261

262

263

264

265

266

267

268

269

270

others. This was because biomass provided enough active adsorption sites, $\mathrm{Mn}(\mathrm{II})$ ions can easily bind with these extra sites. It suggested that in the adsorption system depended on the metal concentration, as long as the adsorption sites on the cell surface did not reach saturation, the removal rate of heavy metals increased. When the number of cells reached a stable level, the effect on the removal rate was not obvious with continuously inoculation. In the case of certain nutrient, the effect of inoculation amount on strain growth was not significant. Therefore, in order to ensure high removal rate and cost savings, excessive inoculum should not be used(Fan et al. 2008). Besides, the pH of the solution with different inoculation amount did not differ significantly.

\section{Effect of pH on biosorption}

In present tests, $\mathrm{pH}$ could affect the ability of B. thuringiensis HM7 adsorption (Fig. 3d). In an acidic condition $(\mathrm{pH}<5)$, there was almost no removal rate and growth of the strain, this was due to the competitive adsorption at low $\mathrm{pH}$, a large amounts of protons like $\mathrm{H}^{+}$and $\mathrm{H}_{3} \mathrm{O}^{+}$increased the difficulty in binding sites of $\mathrm{Mn}^{2+}$ to cell walls, resulting in relatively low adsorption rate. When the $\mathrm{pH}$ was 5.0 , the highest removal rate was reached $(60.88 \%)$, and the biomass achieved a maximum $\mathrm{OD}_{600}$ of 1.66 . This could be attributed to more negatively charged cells become available, promoting a greater metal uptake, and the anionic state of the functional group increased the attraction of ions to $\mathrm{Mn}^{2+}$. However, when the $\mathrm{pH}$ exceeded the appropriate point ( $\mathrm{pH}>7$ ), as it increased, biomass and removal rate would soon decrease. The reasons might be that at higher $\mathrm{pH}$ values, more ligands with negative charges like imidazole, carboxyl, and phosphate groups were exposed which would attract the positive charge metal ions to the cell surface. It could affect the carriers to help transport and the activity of the cell enzyme, thus the adsorption and growth of strain was restricted(Pardo et al. 2003; Wang et al. 2017). In particular, it could be seen that $\mathrm{pH}$ had a significant effect on the growth of the strain, the strain grew well in the weak acid environment (pH57). HM7 reached the maximum growth amount with the initial $\mathrm{pH}$ of 5.0, and the $\mathrm{pH}$ of the solution after the reaction raised to 7.85 from the initial state. In the case of poor growth of the $\mathrm{HM} 7$, the $\mathrm{pH}$ of the solution before and after the reaction did not change significantly (S Fig. 1). This indicated that in the $\mathrm{Mn}$ (II) biosorption, the chemical reaction of HM7 changed the $\mathrm{pH}$ of the solution or secreted alkaline substances(Liao et al. 2015; Wang et al. 2013a).

\section{SEM analysis}

SEM analysis of $B$. thuringiensis HM7 to determine cell surface structure changes under 1,000 mg/L Mn(II) 
271

272

273

274

275

276

277

278

279

280

281

282

283

284

285

286

287

288

289

290

291

292

293

294

295

296

297

stress. The SEM micrographs showed that under normal growth conditions, HM7 had a morphological shape with a smooth surface and an average cell diameter of about $0.5 \mu \mathrm{m}$ (Fig. 4a). The small size of the bacterial structure provided a large contact interface for interaction with metals during biosorption(Zouboulis et al. 2004). After adsorption of $\mathrm{Mn}$ (II), the cell surface morphology considerably changed, the length and size of the cell decreased, and the cells were irregular and cracked with the appearance of wrinkles on the surface, and there were many flocs on the surface of the strain(Fig. 4b). This might be due to the precipitation or adsorption of Mn(II) oxidation on the surface of bacterial cells and the morphological changes caused by the secretion of extracellular polymeric substances during metal biosorption(Chen et al. 2000).

\section{FTIR analysis}

Biosorption depends largely on the physicochemical conditions of the solution and the functional groups of the bacterial cell active site. Therefore, to better understand the types of functional groups involved in the biosorption process, FTIR analysis was performed on HM7 (Iqbal et al. 2009). Intensity and peak position changed before visibly and after adsorption of $\mathrm{Mn}(\mathrm{II})$, and indicated the interaction of the relevant functional groups with $\mathrm{Mn}(\mathrm{II})$ ions in the biosorption process (Fig. 5). The Peak at $3480 \mathrm{~cm}^{-1}$ was shifted to $3000 \mathrm{~cm}^{-1}$ after adsorption corresponded to hydroxyl $\left(\mathrm{OH}^{-}\right)$stretching vibrations(Iqbal et al. 2009). The significant variation of peak of 2360 $\mathrm{cm}^{-1}$ showed that sulfhydryl groups participated in the interaction with $\mathrm{Mn}(\mathrm{II})(\mathrm{Dash}$ et al. 2013). In addition, the spectrum indicated some prominent absorption peaks at 1610,1500, 1410 and $1400 \mathrm{~cm}^{-1}$ showed the presence of carboxyl and amide groups on the surface of bacterial cells(Bharagava \& Mishra 2017). Adsorption peak at 1,400 $\mathrm{cm}^{-1}$ was protein amide I band. The peak ranges of sugars were appeared at 1,000- 1,200 $\mathrm{cm}^{-1}$ (Deng et al. 2013). The $\mathrm{Mn}$ (II) exposed strain biomass also showed two prominent peaks at 830 and $860 \mathrm{~cm}^{-1}$, which represented $\mathrm{CH}=\mathrm{CH}$ of trans-di-substituted alkenes and $-\mathrm{CH}$ out of plane deformation interact with $\mathrm{Mn}(\mathrm{II})($ Bharagava \& Mishra 2017). The results showed that the main component of HM7 surface and strain secretion was a polysaccharide compound containing a large amount of pyrrole ring and protein hydroxyl group. Comparison of FTIR spectra of HM7 before and after Mn(II) adsorption showed that the functional groups such as carboxyl, hydroxyl, sulfhydryl groups, amino, amide I and amide II bands might participate in the complexation of $\mathrm{Mn}$ (II).

Characteristics of the $B$. thuringiensis HM7 in plant growth promoting and antibiotic resistance ability 
It is reported that bacteria increased the biomass yield of plants and reduce the metal toxicity on metal contaminated soil by producing beneficial substances like mineral production of IAA, phosphate solubilization and siderophores(Ma et al. 2016; Zhang et al. 2015). In this study, B. thuringiensis HM7 might produce IAA at the level of $2.55 \mathrm{mg} / \mathrm{L}$ (Table 3), the released of IAA usually caused nutrient absorption and plant biomass to increase, thereby indirectly increased the accumulation of metal in their host(Zhang et al. 2011). In addition, HM7 was able to solubilize mineral phosphate and reached $8.76 \mathrm{mg} / \mathrm{L}$, which would improve the bioavailability of rhizosphere phosphate(Nautiyal et al. 2000). Moreover, HM7 produced siderophores which could promote plant growth and alleviate metal toxicity of the supplement for iron nutrition in plant roots. The production of siderophores formed a strong bond with $\mathrm{Mn}$ (III) during Mn(II) oxygen reaction. Thus, Mn(III) was stabilized by the siderophores-Mn(III) chelate in the reaction(Barboza et al. 2016; Barzanti et al. 2007).

Resistant for Amikacin, Norfloxacin, Gentamycin and Ciprofloxacin. Antibiotics and heavy metals in the environment are potential health hazards due to these properties are usually associated with transmissible plasmids, thus leading to a simultaneous selection of resistance factors for metal ions and antibiotics to suit a variety of harsh environments(Bharagava \& Mishra 2017). Therefore, we believe thatthe object strain could be used as the inoculant for $\mathrm{Mn}(\mathrm{II})$ contaminated water, which may have survival advantages in the rhizosphere, as co-resistance to $\mathrm{Mn}$ (II) and antibiotics, and have potential in the ability to promote plant growth and alleviate metal toxicity.

\section{Discussion}

As an alternative to basic chemical methods, bioremediation has proved to be a viable strategy for Mn (II) removal. Researchers have found that the widely occurring Mn oxides in the natural environment were mainly formed through the action of microorganisms. Microorganisms could catalyze and oxidize $\mathrm{Mn}$ (II) to form oxides, which greatly increased the oxidation rate of Mn(II)(Popp et al. 1990; Stephens 2005). The process of microbial accumulation was related to the metabolism of cells, because the activities of the microorganisms required the participation of metal ions, and when the cells transported these metal ions, some metal ions competed for the adsorption sites, finally formed metal compounds such as oxalic acid salts, carbonates, sulphides, hydroxides(Kuffner et al. 2010). Further studies have found that the adsorption capacity of Mn oxides produced by microbial transformation was generally higher than that of chemically synthesized Mn oxides(Nelson et al. 2002; Tani et al. 2004), and the primary product of bio-manganese oxidation had the activity of catalytic oxidation of 
325

326

327

328

329

330

331

332

333

334

335

336

337

338

339

340

341

342

343

344

345

346

347

348

349

350

351

Mn(II)(Learman et al. 2011). Therefore, the characteristics and applications of microbial removal of Mn have gradually become the current research hotspot.

Bioremediation is a significant way to solve the heavy metal pollution, because it is a cheap and environmentfriendly natural processes with a high degree of public acceptance(Hynes et al. 2008). In recent researches, Hasan showed that $B$. cereus could effectively adsorbed $\mathrm{Mn}$ and $\mathrm{Pb}$ by interacting with environmental factors(Hasan et al. 2016). The research showed that B. cereus was a Mn redox microorganism which isolated from the biofilm of chlorinated drinking water systems(Cerrato et al. 2010). Therefore, Bacillus sp. was considered to be one of the best bacteria for adsorbing heavy metals based on former researches(Barboza et al. 2016). B. thuringiensis is a Gram positive soil bacterium which plays an extremely important role in agricultural production and is often used as a biological pesticide. However, the most study of B. thuringiensis focused on the insecticidal specificity of toxic proteins, the structure and mechanism of toxic proteins, environmental safety and resistance, and the application in agroforestry, the researches on the tolerant and biosorption of heavy metals have not been well researched(de Maagd et al. 2001; Helgason et al. 2000; Nap et al. 2003; Sanahuja et al. 2015; Vachon et al. 2012; Walker et al. 2003).

In recent years, a large number of studies have shown that microorganisms have a good removal effect on heavy metals and the ability to promote plant organisms (Table 3), and HM7 exhibited high Mn(II) tolerance, good Mn(II) removal efficiency and the potential to promote plant growth. Yan et al(2014) claimed that at a certain $\mathrm{Mn}(\mathrm{II})$ concentration, the removal rate of $\mathrm{Mn}(\mathrm{II})$ by Aminobacter $s p$. H1 can reach more than $90 \%$. However, the Mn(II) tolerance of Aminobacter sp. H1(2650 mg/L) was much lower than that of HM7(4000 $\mathrm{mg} / \mathrm{L}$ ). In our previous project, three Mn(II) tolerant strains (B. cereus HM5, B. thuringiensis HM7, R. pickettii HM8) was isolated, the Mn adsorption capacity and characteristics of these strains were studied(Huang et al. 2018; $\mathrm{Xu}$ et al. 2019). The maximum survival concentration and adsorption characteristics of the above strains were different (S Table 1). The results showed that the maximum adsorption capacity of B. cereus HM5 was $593.36 \mathrm{mg} / \mathrm{L}$ at the $\mathrm{Mn}$ concentration of $800 \mathrm{mg} / \mathrm{L}$, the maximum adsorption capacity of $R$. pickettii HM8 was $1,002.83 \mathrm{mg} / \mathrm{L}$ at a $\mathrm{Mn}$ concentration level of $10,000 \mathrm{mg} / \mathrm{L}$, and the maximum adsorption capacity of $B$. thuringiensis $\mathrm{HM} 7$ to $\mathrm{Mn}$ was $693.0417 \mathrm{mg} / \mathrm{L}$ at the $\mathrm{Mn}$ concentration of $2500 \mathrm{mg} / \mathrm{L}$. In addition, we figured out the ability of indoleacetic acid production, siderophore production, and solubilizing P potential. Compared with the other two strains of bacteria, the results indicated that HM7 had the best ability to produce IAA, and 
352

353

354

355

356

357

358

359

360

361

362

363

364

365

366

367

368

369

370

371

372

373

374

375

376

377

378

also had a good ability to produce iron and dissolve phosphorus. Therefore, we believe that $B$. thuringiensis HM7 has a better prospect in dealing with heavy metal pollution in the soil, especially in combination with phytoremediation. .

In this study, we have demonstrated that HM7 promoted Mn(II) oxidation, which is related to the interaction of $\mathrm{Mn}(\mathrm{II})$ with bacterial components or bacterial metabolites. In the $\mathrm{pH}$ test, HM7 reached the maximum growth amount and removal rate when the initial $\mathrm{pH}$ was 5.0, and the solution $\mathrm{pH}$ raised from the initial state to 7.85 after the reaction. We believed that the growth of bacteria would cause changes in $\mathrm{pH}$, which could affect the removal rate. Some published articles also emphasized that $\mathrm{pH}$ was one of the main factors involving $\mathrm{Mn}$ (II) oxidation(Burger et al. 2008; Silva et al. 2012). Biofilm has a significant effect on the adsorption of heavy metals, especially the oxides on the membrane, which played a leading role in the heavy metals biosorption. There are a large number of functional groups on the bacterial cell wall, which directly affect the biosorption of bacteria(Wang et al. 2013a). FTIR indicated that functional groups such as carboxyl, hydroxyl, sulfhydryl groups, amino, amide I and amide II bands could participate in the complexation of $\mathrm{Mn}$ (II), these functional groups could be deprotonated to increase the negative charge on the cell surface and promote electrostatic interaction with the cation. Through SEM analysis, it was found that the surface of the cell changed significantly after the adsorption of Mn(II), indicating that the functional group may interact with the $\mathrm{Mn}$ (II) on the cell surface, and other relevant researches have also been reported(Bharagava \& Mishra 2017; Oves et al. 2012).

In recent years, many studies have demonstrated that microorganisms can secrete metal-chelators (e.g. organic acid, siderophores, and biosurfactants) phosphate solubilization and redox activity to increase bioavailability of metal by plant(Liu et al. 2017; Ma et al. 2011). Azcon et al. assayed that B. cereus, Candida parapsilosis and Arbuscular mycorrhizal fungi could benefit plant growth and nutrient uptake in the heavy metal contaminated soil(Azcón \& Barea 2010). Sheng isolated Pb-resistant strains (Microbacterium sp. and Pseudomonas fluorescens G10) produced siderophores, indole acetic acid and carboxylate deaminase, and increased in total $\mathrm{Pb}$ uptake and biomass production in the bacteria-inoculated plants were obtained(Sheng et al. 2008b). In this study, a high Mn(II)tolerance strain could promote metal bioavailability through metal chelating agent secretion (siderophores), phosphate solubilization and redox activity. Thus, B. thuringiensis HM7 could be used as a biotechnological tool to promote plant development in heavy metal contaminated environments.

Peer) reviewing PDF | (2019:10:42340:1:1:NEW 20 Dec 2019) 


\section{Conclusions}

$\mathrm{Mn}$ is a significant metal that maintains a variety of biological functions, but it can be toxic in high concentrations. Therefore, $\mathrm{Mn}$ (II)-tolerant bacteria can be used as a safe and environmentally friendly alternative to reduce the concentration of metals at the contaminated site. In this study, a $\mathrm{Mn}$ (II)-tolerant strain was isolated from Mn ore soil, the strain had high tolerance to $\mathrm{Mn}$ (II) concentration, good Mn(II) oxidation ability, and the potential to promote plant growth. Compared the relevant researches, the results of this study are meaningful, HM7could be used as an economical, effective and green adsorbent for the removal and recovery of heavy metals from polluted environment, but the complete mechanism underlying Mn(II) oxidation needs further investigation.

\section{Acknowledgement}

The study was supported by Major Science and Technology Program of Hunan Province(2017NK1014); Forestry

Science and Technology Project of Hunan Province (XLK201825, XKL201731); Key Technology R\&D Program of Hunan Province (2016TP2007, 2017TP2006); Key Technology R\&D Program of Changsha (kq1901145); Hunan Natural Science Foundation (2019JJ40013).

Conflicts of Interest: The authors declare no conflict of interest.

\section{References}

Aboushanab RA, Ghanem K, Ghanem N, and Alkolaibe A. 2008. The role of bacteria on heavy-metal extraction and uptake by plants growing on multi-metal-contaminated soils. World Journal of Microbiology \& Biotechnology 24:253-262.

Azcón R, and Barea JM. 2010. Arbuscular Mycorrhizal Fungi, Bacillus cereus, and Candida parapsilosis from a Multicontaminated Soil Alleviate Metal Toxicity in Plants. Microbial Ecology 59:668-677.

Babu AG, Shea PJ, and Oh BT. 2014. Trichoderma sp. PDR1-7 promotes Pinus sylvestris reforestation of leadcontaminated mine tailing sites. Science of the Total Environment s 476-477:561-567.

Barboza NR, Amorim SS, Santos PA, Reis FD, Cordeiro MM, Guerra-Sá R, and Leão VA. 2015. Indirect Manganese Removal by Stenotrophomonas sp. and Lysinibacillus sp. Isolated from Brazilian Mine Water. Biomed Research International 2015:925972.

Barboza NR, Guerra - Sá R, and Leão VA. 2016. Mechanisms of manganese bioremediation by microbes: an overview. Journal of Chemical Technology \& Biotechnology 91:2733-2739.

Barboza NR, Morais MMCA, Queiroz PS, Amorim SS, Guerrasá R, and Leão VA. 2017. High Manganese Tolerance and Biooxidation Ability ofSerratia marcescensIsolated from Manganese Mine Water in Minas Gerais, Brazil. Frontiers in Microbiology 8:1946.

Barzanti R, Ozino F, Bazzicalupo M, Gabbrielli R, Galardi F, Gonnelli C, and Mengoni A. 2007. Isolation and characterization of endophytic bacteria from the nickel hyperaccumulator plant Alyssum bertolonii. Microbial Ecology 53:306-316. 
413

Bharagava RN, and Mishra S. 2017. Hexavalent chromium reduction potential of Cellulosimicrobium sp. isolated from common effluent treatment plant of tannery industries. Ecotoxicology \& Environmental Safety 147:102-109.

Biswas JKB, Anurupa; Rai, Mahendra Kumar; Rinklebe, Jorg; Shaheen, Sabry M; Sarkar, Santosh Kumar; Dash, Madhab Chandra; Kaviraj, Anilava; Langer, Uwe; Song, Hocheol; Vithanage, Meththika; Mondal, Monojit; Niazi, Nabeel Khan. 2018. Exploring potential applications of a novel extracellular polymeric substance synthesizing bacterium (Bacillus licheniformis) isolated from gut contents of earthworm (Metaphire posthuma) in environmental remediation. Biodegradation:1-15.

Burger MS, Mercer SS, Shupe GD, and Gagnon GA. 2008. Manganese removal during bench-scale biofiltration. Water Research 42:4733-4742.

Cerrato JM, Falkinham JO, Dietrich AM, Knocke WR, McKinney CW, and Pruden A. 2010. Manganese-oxidizing and -reducing microorganisms isolated from biofilms in chlorinated drinking water systems. Water Research 44:3935-3945. https://doi.org/10.1016/j.watres.2010.04.037

Chanmugathas P, and Bollag J M. 1986. Microbial Role in Immobilization and Subsequent Mobilization of Cadmium in Soil Suspensions. Soil Sci Soc Am J 51 (5): 1184-1191.

Chen BY, Utgikar VP, Harmon SM, Tabak HH, Bishop DF, and Govind R. 2000. Studies on biosorption of zinc(II) and copper(II) on Desulfovibrio desulfuricans. International Biodeterioration \& Biodegradation 46:11-18.

Chen H, and Zhu Y. 1999. Heavy Metal Pollution in Soils in China: Status and Countermeasures. AMBIO - A Journal of the Human Environment 28:130-134.

Chen L, Luo S, Li X, Wan Y, Chen J, and Liu C. 2014. Interaction of Cd-hyperaccumulator Solanum nigrum L. and functional endophyte Pseudomonas sp. Lk9 on soil heavy metals uptake. Soil Biology \& Biochemistry 68:300308.

Compant S, Clément C, and Sessitsch A. 2010. Plant growth-promoting bacteria in the rhizo- and endosphere of plants: Their role, colonization, mechanisms involved and prospects for utilization. Soil Biology \& Biochemistry 42:669-678.

Crane S, Dighton J, and Barkay T. 2010. Growth responses to and accumulation of mercury by ectomycorrhizal fungi. Fungal Biology 114:873-880.

Das S, Jean JS, Chou ML, Rathod J, and Liu CC. 2016. Arsenite-oxidizing bacteria exhibiting plant growth promoting traits isolated from the rhizosphere of Oryza sativa L.: Implications for mitigation of arsenic contamination in paddies. Journal of Hazardous Materials 302:10-18.

Dash HR, Mangwani N, and Das S. 2013. Characterization and potential application in mercury bioremediation of highly mercury-resistant marine bacterium Bacillus thuringiensis PW-05. Environmental Science \& Pollution Research International 21:2642-2653.

de Maagd RA, Bravo A, and Crickmore N. 2001. How Bacillus thuringiensis has evolved specific toxins to colonize the insect world. Trends in Genetics 17:193-199.

Deng PY, Liu W, Zeng BQ, Qiu YK, and Li LS. 2013. Sorption of heavy metals from aqueous solution by dehydrated powders of aquatic plants. International Journal of Environmental Science \& Technology 10:559566.

Fadel M, Hassanein NM, Elshafei MM, Mostafa AH, Ahmed MA, and Khater HM. 2017. Biosorption of manganese from groundwater by biomass of Saccharomyces cerevisiae. Hbrc Journal 13:106-113.

Fan T, Liu Y, Feng B, Zeng G, Yang C, Ming Z, Zhou H, Tan Z, and Xin W. 2008. Biosorption of cadmium(II), 

zinc(II) and lead(II) by Penicillium simplicissimum : Isotherms, kinetics and thermodynamics. Journal of Hazardous Materials 160:655-661.

Glick BR. 2010. Using soil bacteria to facilitate phytoremediation. Biotechnology Advances 28:367-374.

Gong JF, Zhou YC, Xiao-Yong LI, and Xin R. 2012. Responses of physiological indices of Pinus massoniana seedlings to high manganese stress. Chinese Journal of Ecology 31:520-525.

Hao M, Lu-Ji YU, Ting-Mei LI, and Liu PL. 2016. Screening and Growth Characteristics of a Heterotrophic Nitrification Bacterium. Biotechnology Bulletin:32: 168-174.

Hasan HA, Abdullah SRS, Kofli NT, and Yeoh SJ. 2016. Interaction of environmental factors on simultaneous biosorption of lead and manganese ions by locally isolated Bacillus cereus. Journal of Industrial \& Engineering Chemistry 37:295-305.

Helgason E, Økstad OA, Caugant DA, Johansen HA, Fouet A, Mock M, Hegna I, and Kolstø AB. 2000. Bacillus anthracis, Bacillus cereus, and Bacillus thuringiensis - one species on the basis of genetic evidence. Applied \& Environmental Microbiology 66:2627-2630.

Holt, and John G. 1994. Bergey's manual of determinative bacteriology: Williams \& Wilkins.

Huang HM, Zhao YL, Xu ZG, Zhang W, and Jiang KK. 2019. Physiological responses of Broussonetia papyrifera to manganese stress, a candidate plant for phytoremediation. Ecotoxicology and Environmental Safety 181:18-25. 10.1016/j.ecoenv.2019.05.063.

Huang HM, Zhao YL, Xu ZG, Ding Y, Zhang W, and Wu L. 2018. Biosorption characteristics of a highly Mn(II)resistant Ralstonia pickettii strain isolated from Mn ore. Plos One doi:10.1371/journal.pone.0203285. 10.1371/journal.pone.0203285

Hullo MF, Moszer I, Danchin A, and Martinverstraete I. 2001. CotA of Bacillus subtilis is a copper-dependent laccase. Journal of Bacteriology 183:5426-5430.

Hynes RK, Leung GCY, Hirkala DLM, and Nelson LM. 2008. Isolation, selection, and characterization of beneficial rhizobacteria from pea, lentil, and chickpea grown in western Canada. Canadian Journal of Microbiology 54:248-258.

Iqbal M, Saeed A, and Zafar SI. 2009. FTIR spectrophotometry, kinetics and adsorption isotherms modeling, ion exchange, and EDX analysis for understanding the mechanism of $\mathrm{Cd}(2+)$ and $\mathrm{Pb}(2+)$ removal by mango peel waste. Journal of Hazardous Materials 164:161-171.

Jarpa M, Rozas O, Salazar C, Baeza C, Campos JL, Mansilla HD, and Vidal G. 2016. Comparison of the chemical precipitation, UV/HOand Fenton processes to optimize removal of chronic toxicity from kraft mill effluents. Desalination and Water Treatment 57:13887-13896.

Kamaludeen SPB, Megharaj M, Juhasz AL, Sethunathan N, and Naidu R. 2003. Chromium-Microorganism Interactions in Soils: Remediation Implications. Reviews of environmental contamination and toxicology 178:93164.

Kang CH, Oh SJ, Shin YJ, Han SH, Nam IH, and So JS. 2015. Bioremediation of lead by ureolytic bacteria isolated from soil at abandoned metal mines in South Korea. Ecological Engineering 74:402-407.

Klimek B. 2012. Effect of Long-Term Zinc Pollution on Soil Microbial Community Resistance to Repeated Contamination. Bulletin of Environmental Contamination \& Toxicology 88:617-622.

Kuffner M, Maria SD, Puschenreiter M, Fallmann K, Wieshammer G, Gorfer M, Strauss J, Rivelli AR, and Sessitsch A. 2010. Culturable bacteria from Zn- and Cd-accumulating Salix caprea with differential effects on plant growth and heavy metal availability. Journal of Applied Microbiology 108:1471-1484. 
Kumar S, Stecher G, and Tamura K. 2016. MEGA7: Molecular Evolutionary Genetics Analysis Version 7.0 for Bigger Datasets. Molecular Biology \& Evolution 33:1870-1874.

Learman DR, Wankel SD, Webb SM, Martinez N, Madden AS, and Hansel CM. 2011. Coupled biotic-abiotic $\mathrm{Mn}(\mathrm{II})$ oxidation pathway mediates the formation and structural evolution of biogenic Mn oxides. Geochimica et Cosmochimica Acta 75:6048-6063.

Li XA, and Chen Z. 2010. Correctly Using SPSS Software for Principal Components Analysis. Statistical Research:105-108.

Li Y, Qin CX, Gao B, Hu Y, and Xu H. 2015. Lead-resistant strain KQBT-3 inoculants of Tricholoma lobayensis Heim that enhance remediation of lead-contaminated soil. Environmental Technology 36:2451-2458.

Li Z, Ma Z, Kuijp TJVD, Yuan Z, and Huang L. 2014. A review of soil heavy metal pollution from mines in China: Pollution and health risk assessment. Science of the Total Environment s 468-469:843-853.

Liao J, Feng CL, Ke-Lin LI, Xiang J, and Jin LI. 2015. Influence factors and absorption mechanism of Pb( II ) and $\mathrm{Zn}$ ( II ) by resistant fungus HA. Microbiology China:254-263.

Ling WW, Xiao-Fu WU, Chen YH, Liu Q, and Guo DD. 2011. Screening of manganese-resistant microorganism and their characteristics on Mn (2+) ion removal. Journal of Central South University of Forestry \& Technology 31:152-156.

Liu X, Fu JW, Da SE, Shi XX, Cao Y, Rathinasabapathi B, Chen Y, and Ma LQ. 2017. Microbial siderophores and root exudates enhanced goethite dissolution and $\mathrm{Fe} / \mathrm{As}$ uptake by As-hyperaccumulator Pteris vittata. Environmental Pollution 223:230-237.

Ma Y, Prasad MN, Rajkumar M, and Freitas H. 2011. Plant growth promoting rhizobacteria and endophytes accelerate phytoremediation of metalliferous soils. Biotechnology Advances 29:248-258.

Ma Y, Rajkumar M, Zhang C, and Freitas H. 2016. Beneficial role of bacterial endophytes in heavy metal phytoremediation. Journal of Environmental Management 174:14-25.

Moreira H, Pereira SIA, Marques APGC, Rangel AOSS, and Castro PML. 2019. Effects of soil sterilization and metal spiking in plant growth promoting rhizobacteria selection for phytotechnology purposes. Geofisica internacional 334: 72-81.

Mou D, Yao Y, Yang Y, Zhang Y, Tian C, and Achal V. 2011. Plant high tolerance to excess manganese related with root growth, manganese distribution and antioxidative enzyme activity in three grape cultivars. Ecotoxicology \& Environmental Safety 74:776-786.

Mousavi SM, Motesharezadeh B, Hosseini HM, Alikhani H, and Zolfaghari AA. 2017. Root-induced changes of Zn and $\mathrm{Pb}$ dynamics in the rhizosphere of sunflower with different plant growth promoting treatments in a heavily contaminated soil. Ecotoxicology \& Environmental Safety 147:206.

$\mathrm{N} \mathrm{W}, \mathrm{D}$ vdL, S T, and J V. 2009. Phytoremediation: plant-endophyte partnerships take the challenge. Current Opinion in Biotechnology 20:248-254.

Nap JP, Metz PLJ, Escaler M, and Conner AJ. 2003. The release of genetically modified crops into the environment. Plant Journal for Cell \& Molecular Biology 33:19-46.

Nautiyal CS, Bhadauria S, Kumar P, Lal H, Mondal R, and Verma D. 2000. Stress induced phosphate solubilization in bacteria isolated from alkaline soils. FEMS Microbiology Letters 182:291-296.

Nelson YM, Lion LW, Shuler ML, and Ghiorse WC. 2002. Effect of oxide formation mechanisms on lead adsorption by biogenic manganese (hydr)oxides, iron (hydr)oxides, and their mixtures. Environmental Science \& Technology 36:421-425.

Peer) reviewing PDF | (2019:10:42340:1:1:NEW 20 Dec 2019) 
Orlowska E, PrzybyLowicz W, Orlowski D, Turnau K, and Mesjasz-PrzybyLowicz J. 2011. The effect of mycorrhiza on the growth and elemental composition of Ni-hyperaccumulating plant Berkheya coddii Roessler. Environmental Pollution 159:3730-3738.

Ouyang LN, Xiao-Fu WU, Yun LI, Feng CL, and Chen YH. 2016. Growth and heavy metal accumulation of Paulownia fortunei and Koelreuteria bipinnata in an ecological restoration site of the manganese-ore tailing. China Environmental Science 36:908-916.

Oves M, Khan MS, and Zaidi A. 2012. Biosorption of heavy metals by Bacillus thuringiensis strain OSM29 originating from industrial effluent contaminated north Indian soil. Saudi Journal of Biological Sciences 20:121129.

Pardo R, Herguedas M, Barrado E, and Vega M. 2003. Biosorption of cadmium, copper, lead and zinc by inactive biomass of Pseudomonas Putida. Analytical \& Bioanalytical Chemistry 376:26-32.

Ping Y, Jiang LY, Chen JM, Zhi-Min HE, Xiao SD, and Jiang YF. 2014. Isolation and Identification of Mn Oxidizing Bacterium Aminobacter sp. H1 and Its Oxidation Mechanism. Environmental Science 35:1428-1436.

Popp JL, Kalyanaraman B, and Kirk TK. 1990. Lignin peroxidase oxidation of Mn2+ in the presence of veratryl alcohol, malonic or oxalic acid, and oxygen. Biochemistry 29:10475-10480.

Rajkumar M, Ae N, Prasad MNV, and Freitas H. 2010. Potential of siderophore-producing bacteria for improving heavy metal phytoextraction. Trends in Biotechnology 28:142-149.

Saitou NNM, and Nei MC. 1987. Saitou N, Nei M.. The Neighbor-Joining Method-a New Method for Reconstructing Phylogenetic Trees. Mol Biol Evol 4: 406-425. 4:406-425.

Sanahuja G, Banakar R, Twyman RM, Capell T, and Christou P. 2015. Bacillus thuringiensis: a century of research, development and commercial applications. Plant Biotechnology Journal 9:283-300.

Schwyn B, and Neilands JB. 1987. Universal chemical assay for the detection and determination of siderophores. Analytical Biochemistry 160:47-56.

Sheng X, He L, Wang Q, Ye H, and Jiang C. 2008a. Effects of inoculation of biosurfactant-producing Bacillus sp. J119 on plant growth and cadmium uptake in a cadmium-amended soil. Journal of Hazardous Materials 155:1722.

Sheng XF, Xia JJ, Jiang CY, He LY, and Qian M. 2008b. Characterization of heavy metal-resistant endophytic bacteria from rape (Brassica napus) roots and their potential in promoting the growth and lead accumulation of rape. Environmental Pollution 156:1164-1170.

Silva AM, Cunha EC, Silva FDR, and Leão VA. 2012. Treatment of high-manganese mine water with limestone and sodium carbonate. Journal of Cleaner Production 29-30:11-19.

Stephens TH. 2005. Microbial Manganese Oxidation in the Lower Mississippi River: Methods and Evidence. Geomicrobiology Journal 22:117-125.

Tang W, Gong J, Wu L, Li Y, Zhang M, and Zeng X. 2016. DGGE diversity of manganese mine samples and isolation of a Lysinibacillus sp. efficient in removal of high Mn (II) concentrations. Chemosphere 165:277-283.

Tani Y, Ohashi M, Miyata N, Seyama H, Iwahori K, and Soma M. 2004. Sorption of Co(II), Ni(II), and Zn(II) on biogenic manganese oxides produced by a Mn-oxidizing fungus, strain KR21-2. Environmental Letters 39:26412660.

Tuffin I, Hector S, Sm, and Rawlings D. 2006. Resistance determinants of a highly arsenic-resistant strain of Leptospirillum ferriphilum isolated from a commercial biooxidation tank. Applied \& Environmental Microbiology 72:2247-2253. 
Vachon V, Laprade R, and Schwartz JL. 2012. Current models of the mode of action of Bacillus thuringiensis insecticidal crystal proteins: a critical review. Journal of Invertebrate Pathology 111:1-12.

Walker K, Mendelsohn M, Matten S, Alphin M, and Ave D. 2003. The Role of Microbial Bt Products in U.S. Crop Protection. Journal of New Seeds 5:31-51.

Wang J, Yang D, Zhang Y, Shen J, Gast CVD, Hahn MW, and Wu Q. 2011. Do Patterns of Bacterial Diversity along Salinity Gradients Differ from Those Observed for Macroorganisms? Plos One 6:e27597.

Wang P, Ma Y, Wang C, Zhang S, and Cheng S. 2015. Isolation and characterization of heavy metal-resistant bacterias capable of removing Cr(VI). Polish journal of environmental studies 24:339-345.

Wang T, Yao J, Yuan Z, Zhao Y, Wang F, and Chen H. 2017. Isolation of lead-resistant Arthrobactor strain GQ-9 and its biosorption mechanism. Environmental Science \& Pollution Research:1-12.

Wang Y, Feng HE, You J, Chen K, Bingqin XU, and Lin Y. 2013a. Screening and Identification of a Manganeseresistant Strain and Its Manganese Biosorption Conditions. Acta Agriculturae Boreali-Occidentalis Sinica 22:193-199.

Wang Y, Feng HE, You J, Chen K, Bingqin XU, and Lin Y. 2013b. Screening and Identification of a Manganeseresistant Strain and Its Manganese Biosorption Conditions. Acta Agriculturae Boreali-Occidentalis Sinica 9:3542.

Wani PA, Khan MS, and Zaidi A. 2007. Chromium reduction, plant growth-promoting potentials, and metal solubilizatrion by Bacillus sp. isolated from alluvial soil. Current Microbiology 54:237-243.

Xu ZG, Ding Y, Huang HM, Wu L, Zhao YL, and Yang GY. 2019. Biosorption Characteristics of Mn (II) by Bacillus cereus Strain HM-5 Isolated from Soil Contaminated by Manganese Ore. Polish journal of environmental studies 28:1-10. DOI: 10.15244/pjoes/84838.

Yan P, Jiang LY, Chen JM, He ZM, Xiao SD, and Jiang YF. 2014. Isolation and identification of Mn oxidizing bacterium Aminobacter sp. H1 and its oxidation mechanism. Environmental Science 35:1428-1436.

Yu J, Juanjuan Q, Ying L, Haidong G, and Lilong Y. 2013. Isolation, identification and $\mathrm{Pb}$ (II) biosorption characterization of a lead-resistant strain. Acta Scientiae Circumstantiae 33:2248-2255.

Zaidi S, Usmani S, Singh BR, and Musarrat J. 2006. Significance of Bacillus subtilis strain SJ-101 as a bioinoculant for concurrent plant growth promotion and nickel accumulation in Brassica juncea. Chemosphere 64:991-997.

Zhang WH, He LY, Wang Q, and Sheng XF. 2015. Inoculation with endophytic Bacillus megaterium 1Y31 increases $\mathrm{Mn}$ accumulation and induces the growth and energy metabolism-related differentially-expressed proteome in Mn hyperaccumulator hybrid pennisetum. Journal of Hazardous Materials 300:513-521.

Zhang YF, He LY, Chen ZJ, Wang QY, Qian M, and Sheng XF. 2011. Characterization of ACC deaminaseproducing endophytic bacteria isolated from copper-tolerant plants and their potential in promoting the growth and copper accumulation of Brassica napus. Chemosphere 83:57-62.

Zhao X, Wang X, Liu B, Xie G, and Xing D. 2018. Characterization of manganese oxidation by Brevibacillus at different ecological conditions. Chemosphere 205:553-558.

Zouboulis AI, Loukidou MX, and Matis KA. 2004. Biosorption of toxic metals from aqueous solutions by bacteria strains isolated from metal-polluted soils. Process Biochemistry 39:909-916.

PeerJ reviewing PDF | (2019:10:42340:1:1:NEW 20 Dec 2019) 


\section{Figure Legends}

617 Fig. 1 Phylogenetic relationships by a neighboring analysis of the 16S rRNA gene sequences showing the position 618 of the strain HM7.

619 Fig. 2 The relationship between B. thuringiensis HM7 growth, removal rate of Mn(II) and system $\mathrm{pH}$ at different $620 \mathrm{Mn}(\mathrm{II})$ concentrations. The upper left ordinate represents the strain growth curve OD600, the upper right ordinate 621 represents $\mathrm{pH}$, and the lower left ordinate represents the strain's removal rate of manganese. The cultured condition 622 was the $\mathrm{Mn}$ (II) concentration of $1,000 \mathrm{mg} / \mathrm{L}$, the cultured time was $72 \mathrm{~h}$, the temperature was $30^{\circ} \mathrm{C}$, the inoculation 623 biomass was $1 \mathrm{~mL}$.

624 Fig. 3 The relationship between growth and removal rate of Mn(II) under different time (a), different temperature 625 (b), different inoculation dose (c) and different $\mathrm{pH}$ (d). In general, the initial culture conditions were $\mathrm{Mn}(\mathrm{II})$ 626 concentration $1000 \mathrm{mg} / \mathrm{L}$, temperature $30^{\circ} \mathrm{C}$ and $\mathrm{pH} 5.6-5.8$ for $72 \mathrm{~h}$. and change one of the corresponding factors 627 under the single factor experiment.

628 Fig. 4 SEM micrograph of HM7 cells surface before adsorption (a) and after adsorption (b) under the conditions 629 of initial $\mathrm{Mn}$ (II) concentration $1000 \mathrm{mg} / \mathrm{L}$, temperature $30^{\circ} \mathrm{C}$ and $\mathrm{pH} 5.6-5.8$ for $72 \mathrm{~h}$.

630 Fig. 5 FTIR of $B$. thuringiensis HM7 before and after adsorption of Mn(II) under the conditions of initial Mn(II) 631 concentration $1,000 \mathrm{mg} / \mathrm{L}$, temperature $30{ }^{\circ} \mathrm{C}$ and $\mathrm{pH} 5.6-5.8$ for $72 \mathrm{~h}$. 


\section{Table Legends}

633 Table 1 Recent examples of phytoremediation promotion by microbes.

634 Table 2 Morphological and biochemical characteristics of B. thuringiensis HM7.

635 Table 3 Characteristics of the $B$. thuringiensis HM7 in plant growth promoting and antibiotic resistance ability. 


\section{Supplementary Fig legends}

637 Supplementary Fig. 1 The relationship between growth and pH under different time (a), different temperature (b), 638 different inoculation dose (c) and different $\mathrm{pH}$ (d). In general, the initial culture conditions were $\mathrm{Mn}$ (II)

639 concentration $1000 \mathrm{mg} / \mathrm{L}$, temperature $30^{\circ} \mathrm{C}$ and $\mathrm{pH} 5.6-5.8$ for $72 \mathrm{~h}$. and change one of the corresponding factors 640 under the single factor experiment. 


\section{Supplementary Table Legends}

643 Supplementary Table 1 Comparison of Characteristics among the B. cereus HM5, B. thuringiensis HM7, and $R$. 644 pickettii HM8 in plant growth promoting and antibiotic resistance ability.

645 


\section{Figure 1}

\section{Phylogenetic relationships by a neighboring analysis of the 16S rRNA gene sequences showing the position of the strain HM7}

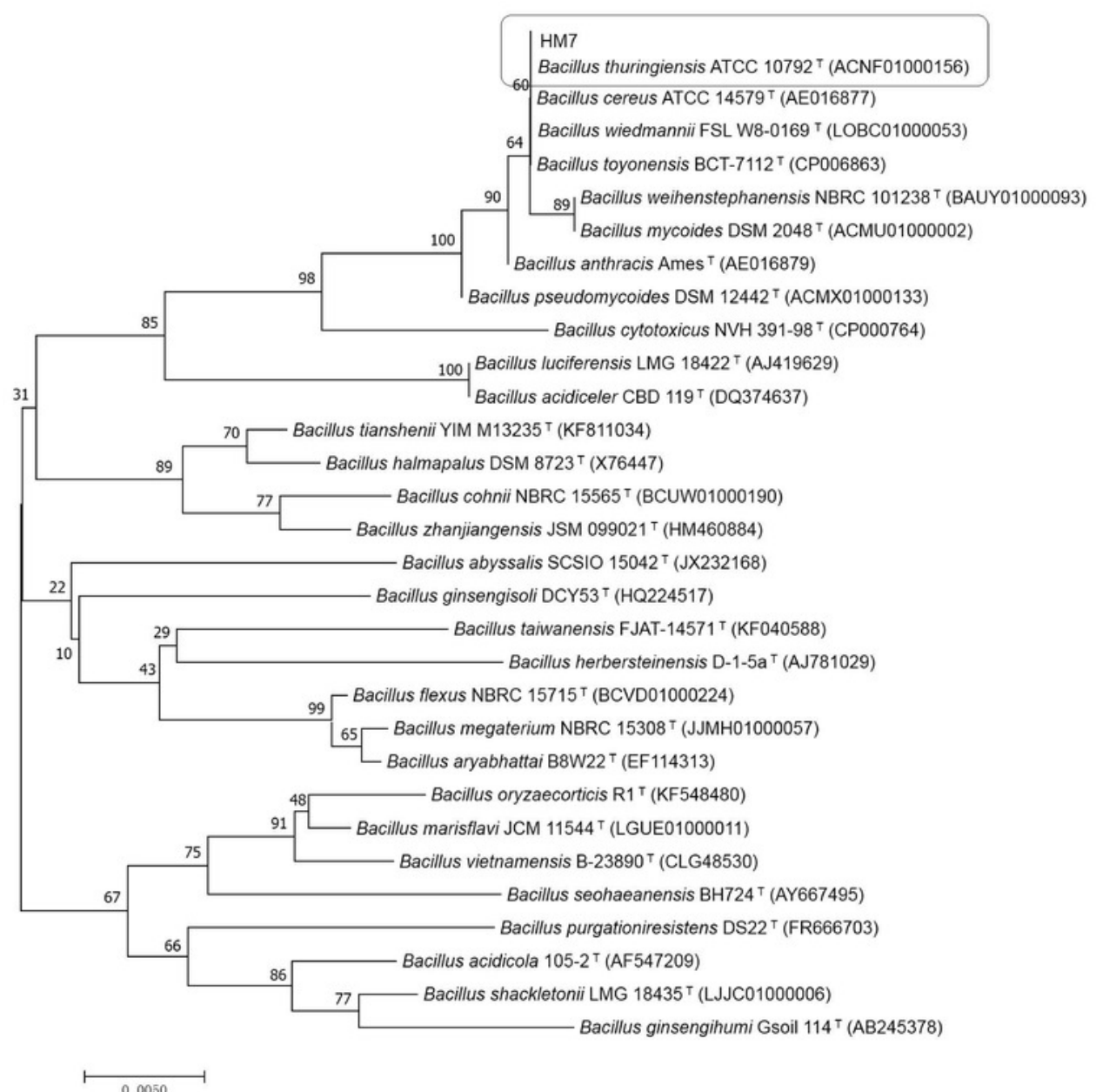


Figure 2

The relationship between $B$. thuringiensis HM7 growth, removal rate of $\mathrm{Mn}(\mathrm{II})$ and system $\mathrm{pH}$ at different $\mathrm{Mn}$ (II) concentrations.
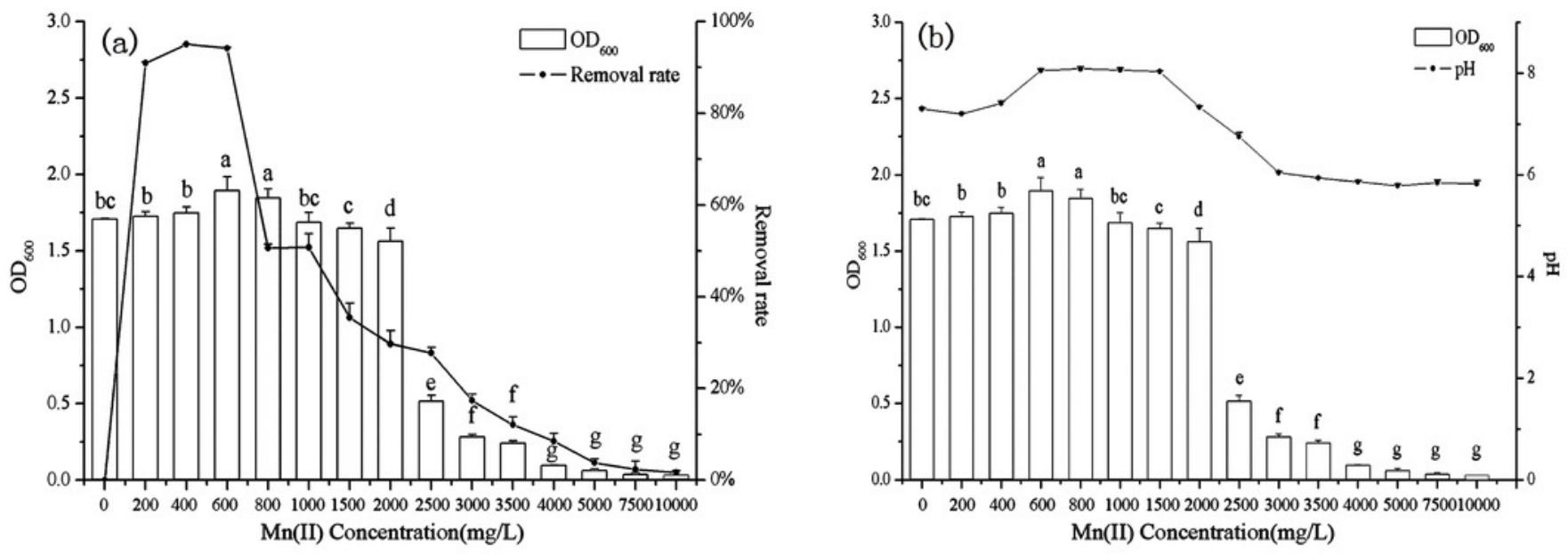
Figure 3

The relationship between growth and removal rate of $\mathrm{Mn}$ (II) under different culture conditions.
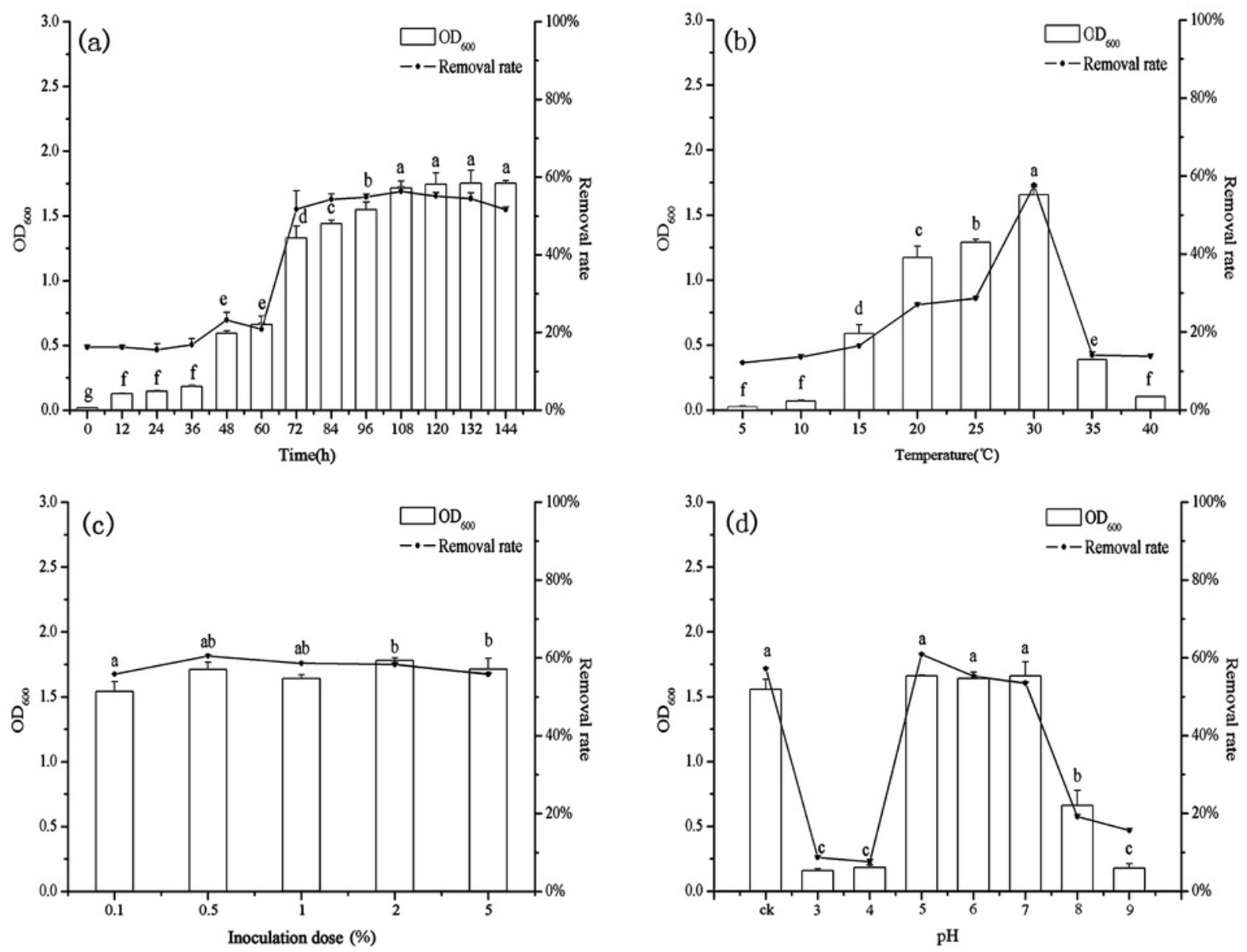
Figure 4

SEM micrographs of HM7.
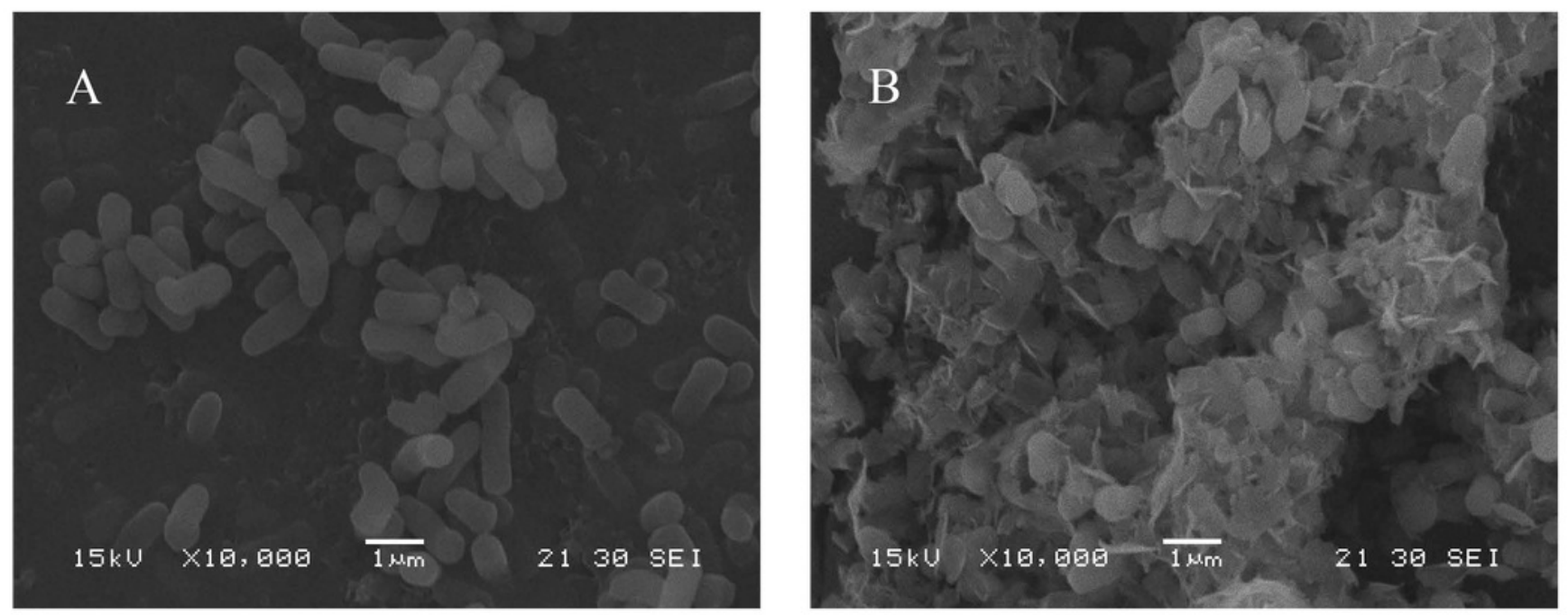
Figure 5

FTIR of $B$. thuringiensis HM7 before and after adsorption of Mn(II).

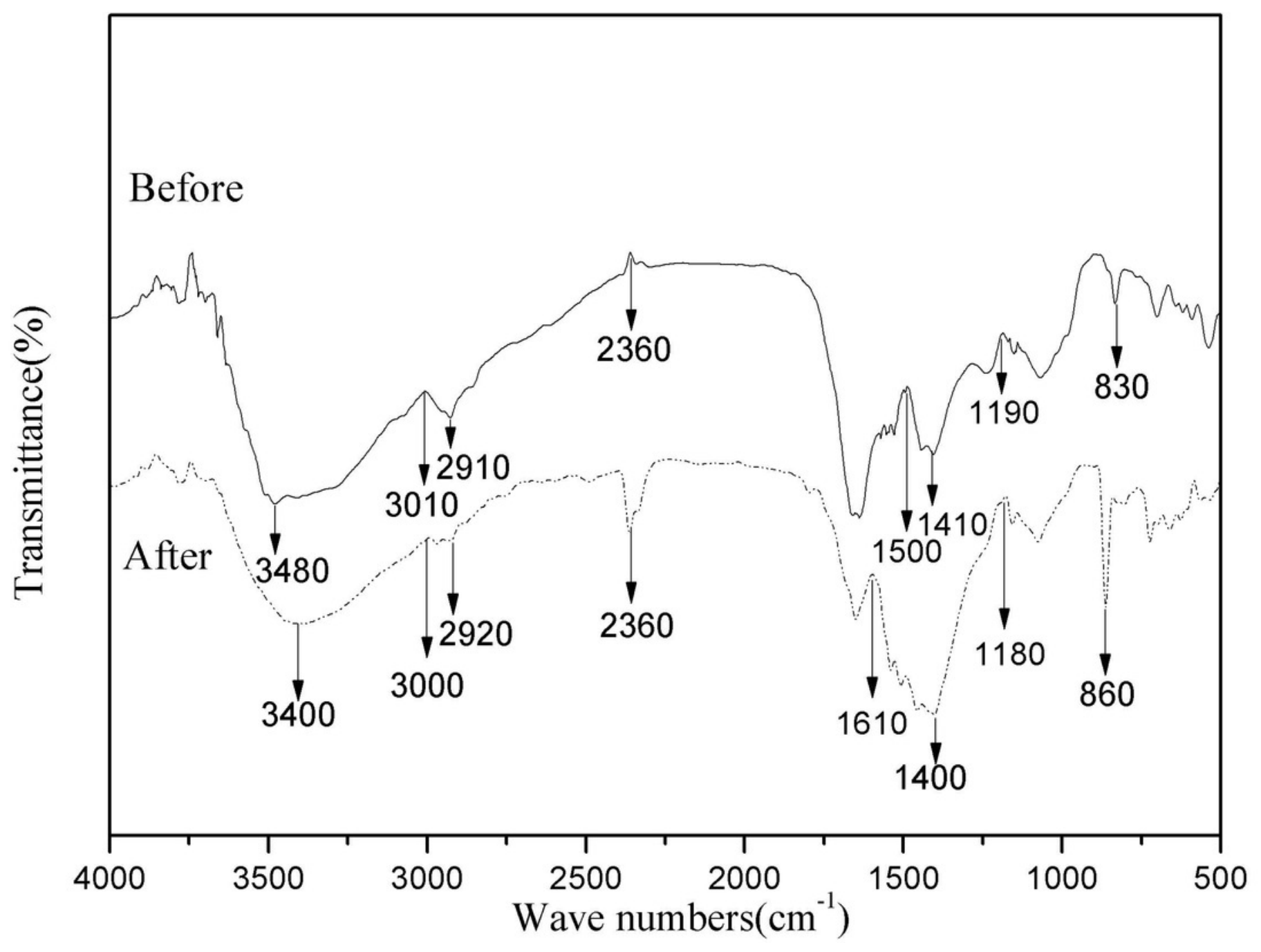




\section{Table 1 (on next page)}

Recent examples of phytoremediation promotion by microbes. 
1

2

3

Table1 Recent examples of phytoremediation promotion by microbes

\begin{tabular}{|c|c|c|c|c|}
\hline Microorganisms & Plants & Mechanisms of microorganisms & $\begin{array}{l}\text { Effect of microorganism on plant } \\
\text { under the heavy metal pollution }\end{array}$ & References \\
\hline $\begin{array}{l}\text { Bacillus } \\
\text { licheniformis }\end{array}$ & Vigna radiata & $\begin{array}{l}\text { The bacteria produced indole } \\
\text { acetic acid and had the ability of } \\
\text { phosphate solubilisation. }\end{array}$ & $\begin{array}{l}\text { The bacterium offered potential of } \\
\text { plant growth promotion and the } \\
\text { ability to } \mathrm{Cu}(\mathrm{II})(34.5 \%) \text { and } \mathrm{Zn}(\mathrm{II}) \\
(54.4 \%) \text { removal. }\end{array}$ & (Biswas 2018) \\
\hline $\begin{array}{l}\text { Bacillus safensis } \\
\text { FO-036b, } \\
\text { Pseudomonas } \\
\text { fluorescens } \\
\text { p.f.169 }\end{array}$ & $\begin{array}{l}\text { Helianthus } \\
\text { annuus L. }\end{array}$ & $\begin{array}{l}\text { The bacterium produced the } \\
\text { intensification of the rhizosphere } \\
\text { process and changed EC, pH and } \\
\text { dissolved organic carbon in the } \\
\text { rhizosphere. }\end{array}$ & $\begin{array}{l}\text { The treatments with inoculation } \\
\text { reduced the exchangeable } \mathrm{Pb} \text { (from } \\
10.34 \% \text { to } 25.92 \% \text { ) and } \mathrm{Zn} \text { (from } \\
13.68 \% \text { to } 30.82 \% \text { ) in the } \\
\text { rhizosphere. }\end{array}$ & $\begin{array}{l}\text { (Mousavi et } \\
\text { al. 2017) }\end{array}$ \\
\hline $\begin{array}{l}\text { Bacillus flexus } \\
\text { ASO-6 }\end{array}$ & Oryza sativa, & $\begin{array}{l}\text { The strain showed high resistant } \\
\text { to As ( } 32 \text { and } 280 \mathrm{mM} \text { ) and } \\
\text { exhibiting elevated rates of } \\
\text { As(III) oxidation. The ability of } \\
\text { producing IAA, siderophore and } \\
\text { to solubilize phosphate. }\end{array}$ & $\begin{array}{l}\text { The bacterial inoculation increased } \\
\text { grain yield, straw yield, and root } \\
\text { biomass in the rice plant and As } \\
\text { accumulation in straw and grain } \\
\text { decreased significantly. }\end{array}$ & $\begin{array}{l}\text { (Das et al. } \\
2016)\end{array}$ \\
\hline $\begin{array}{l}\text { Bacillus } \\
\text { megaterium } \\
1 \mathrm{Y} 31\end{array}$ & Pennisetum & $\begin{array}{l}\text { The strain could produce IAA and } \\
\text { effect the leaf differentially } \\
\text { expressed proteins (e.g., } \\
\text { photosynthesis, energy } \\
\text { generation, metabolisms, and } \\
\text { response to stimulus). }\end{array}$ & $\begin{array}{l}\text { The strain increased the total } \mathrm{Mn} \\
\text { uptake (ranging from } 23 \% \text { to } \\
112 \% \text { ) and dry weights (ranging } \\
\text { from } 28 \% \text { to } 94 \% \text { ) of pennisetum } \\
\text { with treated compared to the } \\
\text { control. }\end{array}$ & $\begin{array}{l}\text { (Zhang et al. } \\
\text { 2015) }\end{array}$ \\
\hline $\begin{array}{l}\text { Bacillus } \\
\text { thuringiensis } \\
\text { KQBT-3 }\end{array}$ & $\begin{array}{l}\text { Tricholoma } \\
\text { lobayensis }\end{array}$ & $\begin{array}{l}\text { The inoculating of KQBT-3 } \\
\text { further induced oxidative } \\
\text { response and alleviated lipid } \\
\text { peroxidation in the plant due to } \\
\mathrm{Pb} \text { accumulation. }\end{array}$ & $\begin{array}{l}\text { KQBT- } 3 \text { could decrease } \\
\text { malondialdehyde in the plant, } \\
\text { biomass and accumulation of } \mathrm{Pb} \\
\text { increased } 47.3 \% \text { and } 33.2 \% \text {, } \\
\text { respectively. }\end{array}$ & (Li et al. 2015) \\
\hline $\begin{array}{l}\text { Trichoderma sp. } \\
\text { PDR1-7 }\end{array}$ & $\begin{array}{l}\text { Pinus } \\
\text { sylvestris }\end{array}$ & $\begin{array}{l}\text { PDR1-7 participated in the } \\
\text { antioxidative defence process in } \\
\text { the plants to facilitate nutrient } \\
\text { uptake and by reducing heavy } \\
\text { metal stress. }\end{array}$ & $\begin{array}{l}\text { PDR 1-7 promote plant growth and } \\
\text { improve the absorption of } \mathrm{As}, \mathrm{Cd} \text {, } \\
\mathrm{Cu}, \mathrm{Ni}, \mathrm{Pb} \text {, and } \mathrm{Zn} \text {. }\end{array}$ & $\begin{array}{l}\text { (Babu et al. } \\
\text { 2014) }\end{array}$ \\
\hline $\begin{array}{l}\text { Pseudomonas } \\
\text { sp. Lk9 }\end{array}$ & $\begin{array}{l}\text { Solanum } \\
\text { nigrum } L .\end{array}$ & $\begin{array}{l}\text { Lk9 could improve } \mathrm{P} \text { and soil Fe } \\
\text { mineral nutrition supplies and } \\
\text { secrete organic acids to enhance } \\
\text { soil heavy metal availability. }\end{array}$ & $\begin{array}{l}\text { After inoculation, } S \text {. nigrum } \\
\text { increased shoot dry biomass by } \\
14 \% \text { and the total of Cu by } 16.0 \% \text {, } \\
\text { Zn by } 16.4 \% \text { and } \mathrm{Cd} \text { by } 46.6 \% \\
\text { accumulated in aerial parts. }\end{array}$ & $\begin{array}{l}\text { (Chen et al. } \\
\text { 2014) }\end{array}$ \\
\hline
\end{tabular}




\begin{tabular}{|c|c|c|c|c|}
\hline$A M F$ & $\begin{array}{l}\text { Dendrocalamu } \\
\text { s strictus }\end{array}$ & $\begin{array}{l}\text { The strain could promote nutrient } \\
\text { absorption in the plant (e.g., } \mathrm{P}, \mathrm{K} \text {, } \\
\mathrm{Ca}, \mathrm{Mg} \text {, ect.). }\end{array}$ & $\begin{array}{l}\text { The content of } \mathrm{Fe} \text { and } \mathrm{Al} \text { were } \\
\text { reduced in plants. }\end{array}$ & $\begin{array}{l}\text { (Babu and } \\
\text { Reddy 2011). }\end{array}$ \\
\hline Bacillus sp. & $\begin{array}{l}\text { Brassica } \\
\text { campestris L. }\end{array}$ & $\begin{array}{l}\text { The strain had high resistant to } \\
\mathrm{Cr}, \mathrm{Zn} \text {, and } \mathrm{Pb} \text {, and secreted } \\
\text { organic acid. }\end{array}$ & The strain promote plant growth. & $\begin{array}{l}\text { (Wani et al. } \\
2007\end{array}$ \\
\hline
\end{tabular}


Table 2 (on next page)

Morphological and biochemical characteristics of $B$. thuringiensis HM7. 


\begin{tabular}{ll}
\hline Tests employed & Characteristics observed \\
\hline Morphology & + \\
Gram reaction & Short rod \\
Shape & - \\
Pigments & \\
Biochemical reactions & + \\
Catalase & - \\
Hydrogen sulfide & + \\
Methyl red & + \\
Voges Proskauer & + \\
Oxidase & + \\
Glucose & + \\
Gelatin & + \\
\hline
\end{tabular}

“+” and “_" indicate positive and negative reactions, respectively 


\section{Table 3(on next page)}

Characteristics of the $B$. thuringiensis HM7 in plant growth promoting and antibiotic resistance ability. 
1 Table 3 Characteristics of the B. thuringiensis HM7 in plant growth promoting and antibiotic resistance ability.

\begin{tabular}{ll}
\hline Tests employed & Characteristics \\
\hline Plant growth promoting ability & \\
IAA (mg/L) & $2.55 \pm 0.043$ \\
Phosphate Solubilization (mg/L) & $8.76 \pm 0.617$ \\
Siderophores production & + \\
Antibiotic resistance & \\
Cefazolin (30 mcg) & $\mathrm{S}$ \\
Amikacin $(5 \mathrm{mcg})$ & $\mathrm{R}$ \\
Chloramphenicol (30 mcg) & $\mathrm{S}$ \\
Erythromycin (15 mcg) & $\mathrm{S}$ \\
Trimethoprim (5 mcg) & $\mathrm{S}$ \\
Norfloxacin (10 mcg) & $\mathrm{R}$ \\
Gentamycin (10 mcg) & $\mathrm{R}$ \\
Ciprofloxacin $(5 \mathrm{mcg})$ & $\mathrm{R}$ \\
Penicillin $\mathrm{G}(10 \mathrm{units})$ & $\mathrm{S}$ \\
Ampicillin $(10 \mathrm{mcg})$ & \\
\hline
\end{tabular}

